\title{
Religionens teknik og teknikkens religion
}

\author{
NIELS REEH
}

\begin{abstract}
ENGLISH ABSTRACT: This article seeks to utilize the German philosopher Martin Heidegger's notion of Gestell to establish an outline of the relation between religion and technique including media technique. According to Heidegger, technique on the one hand serves as a means for Man. On the other hand technique also embeds Man in new relations as a standing reserve for something else. The article suggests that media technology has contributed to embed Man in religious and national distinctions. On this basis, the article presents an outline of different historical stages in which technology and especially media technology has had crucial consequences for embeding Man in religious and national distinctions.
\end{abstract}

DANSK RESUME: I denne artikel opstilles en skitse af hoordan forholdet mellem religion og teknik, herunder medier kan begribes ved hjælp af Martin Heideggers begreb Gestell. Dette begreb skærper opmærksomheden på det forhold at teknik ikke kun er et middel for mennesket, men også indlejrer mennesket i nye relationer. Mennesket bliver via teknikken stillet til rådighed eller som Heidegger kaldte det en bestand for noget andet end sig selv $i$ disse nye relationer. I det lange historiske perspektiv har teknikken og især medieteknikken bidraget til at indlejre mennesket og dets livsverden i en række nye sammenhænge, heriblandt det man med udgangspunkt $i$ Jan Assmann kunne kalde forskellige former for religiøse, statslige og nationale distinktioner, der har spillet afgørende roller i menneskets historie. På denne baggrund opstiller artiklen en skitse over sammenhænge mellem medieteknik og religionsformer.

KEY WORDS: Martin Heidegger; religion; technology.

\section{Indledning}

Religion og medier har igennem de seneste år været et emne, der pådraget sig en betydelig opmærksomhed. I en nordisk kontekst er det nok især medieforskeren Stig Hjarvard, der er brudt igennem den akademiske lydmur med begrebet mediatization (Hjarvard 2012). Ser man efter, er et karakteristika ved Hjarvard og størstedelen af forskningslitteraturen om religion og medier imidlertid, at analyserne i for høj grad har været løsrevet fra andre sociale praktikker som fx de praktikker, der ligger bag konstruktionen af en stat (for en oversigt se Campbell \& Vitullo 2016). I denne artikel 
jeg forsøge at anlægge et bredere perspektiv og skitsere en mere gennemgribende analyse af forholdet mellem religion og teknik.

\section{Hvad er teknik?}

I det følgende vil jeg tage udgangspunkt i filosoffen Martin Heideggers lille skrift Spørgsmålet om teknikken, som jeg vil bruge samtidig med, at jeg vil tillade mig at forholde mig relativt frit til Heideggers tanker (Heidegger 1999). Det bør i denne sammenhæng nævnes, at dette skrift har været en væsentlig inspiration for Michel Foucault (Dreyfus 1996). Indledningsvis gør Heidegger opmærksom på, at teknik almindeligvis betragtes som et middel til at opnå et mål og som en menneskelig praksis (Heidegger 1999, 37). Man kan sige, at teknik her anskues teleologisk. Et middel, inklusive teknik, kan imidlertid også anskues kausalt eller som en årsag til noget andet. Heidegger bygger her formodentlig videre på Hegels sammenføjning af det teleologiske og kausale perspektiv i sit begreb praktische Verhaltnis zur Natur (de Vries 1991). Dette har siden har spillet en afgørende rolle blandt såkaldt venstrehegelianere eller praksisteoretikere som fx Louis Althusser, Michel Foucault og Pierre Bourdieu, Thomas Højrup og mange flere. Samlet set er de begrebslogiske forudsætninger for subjektets praksis blevet formaliseret af Thomas Højrup (Højrup 2002, 95):

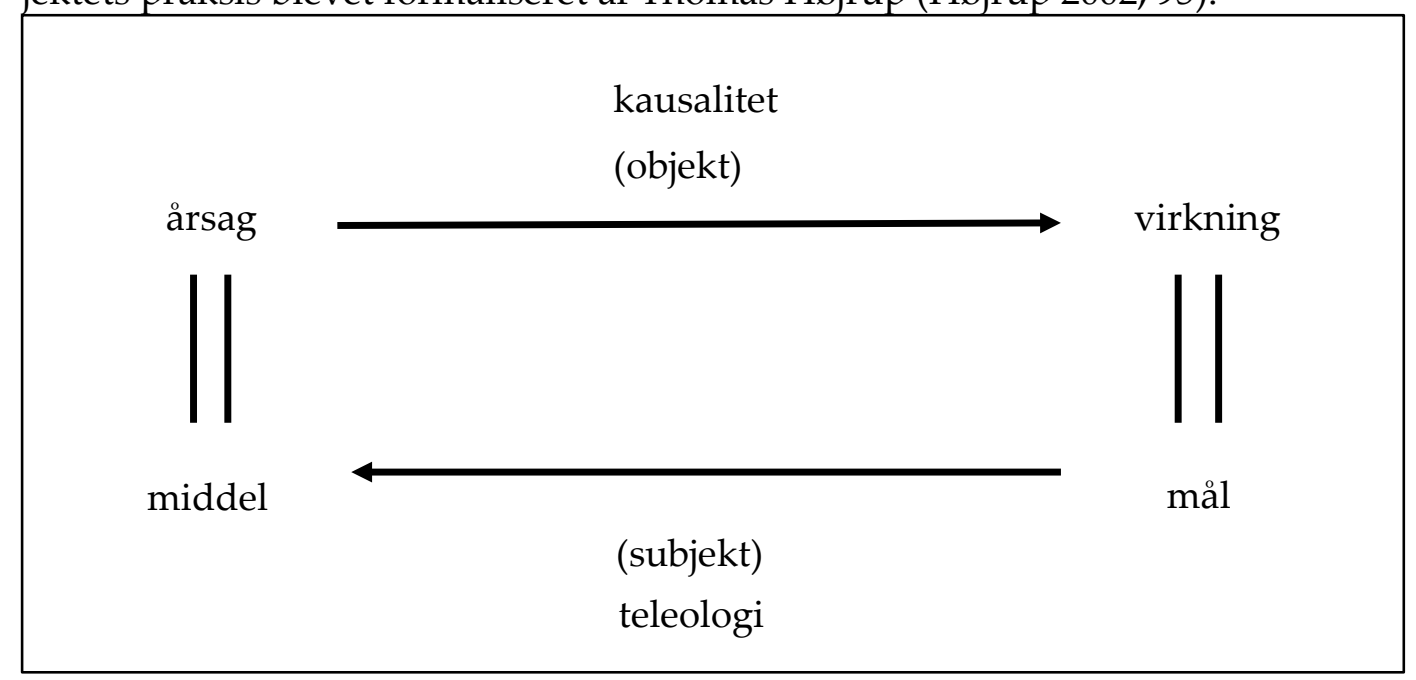

Menneskets praksis, inklusive teknik, kan imidlertid også formelt anskues i et tidsligt forløb eller som historiske kæder af målsætninger med dertil hørende valg af midler, som medfører forandringer, som mennesket igen handler på baggrund af: 


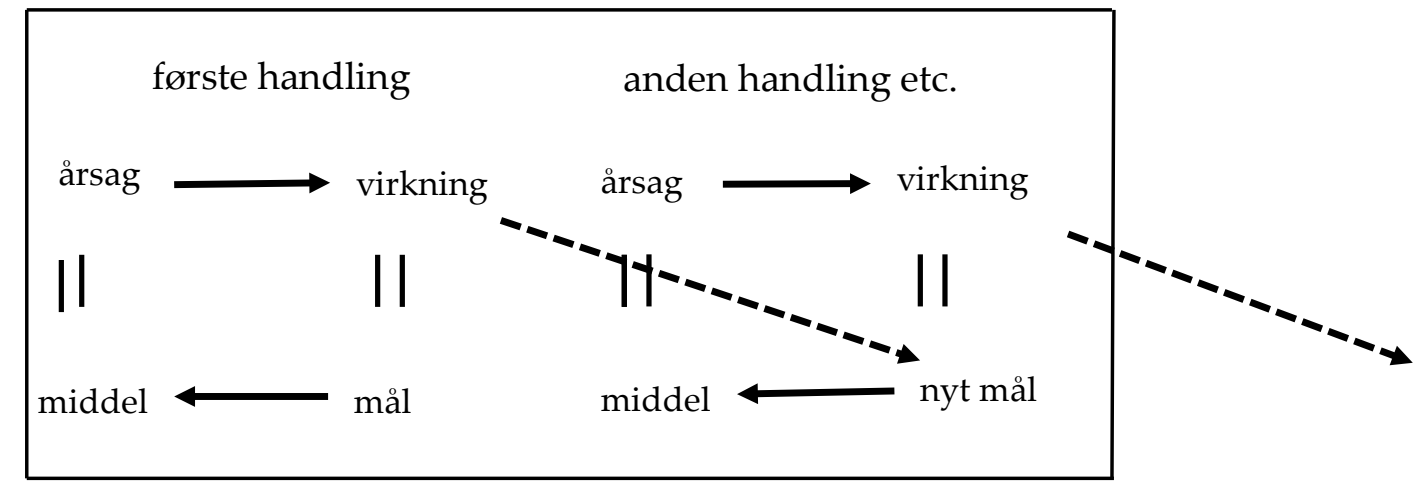

Sådanne historiske kæder af årsager og virkninger samt menneskelige valg af mål og midler har naturligvis også spillet en vigtig rolle i sociologien i bredest mulige forstand i form af $\mathrm{fx}$ begreber som tilsigtede og utilsigtede konsekvenser, strukturelle årsager mm. I sit lille skrift skærper Heidegger imidlertid opmærksomheden mht. at teknikken netop ikke kun er et middel til et mål:

Vandkraftværket er stillet i Rhinstrømmen. Det stiller den med henblik på dens vandtryk, som tilstiller turbinerne at dreje og ved denne omdrejning drive den maskine...for hvis skyld højspændingscentralen er bestilt med dens ledningsnet til befordring af strøm. I området for disse indgribende følger af bestillingen af elektrisk energi fremtræder også Rhinstrømmen som noget bestilt...og indespærret i kraftværket (Heidegger 1999, 45).

Teknikken bevirker altså ifølge Heidegger, at naturen stilles ind i - eller indlejres i en ny sammenhæng som forandrer menneskets forhold til naturen. Teknikken bevirker, at naturen afdækkes (for mennesket) på en ny måde, nemlig som det Heidegger kalder for 'bestand'(Bestand), hvilket vil sige, at naturen nu består i at være til rådighed for industriel udnyttelse, hvilket var den romantisk sindede Heidegger imod. Uanset hvad man måtte mene om Heideggers romantiserende forhold til naturen, peger han imidlertid på, at mennesket selv også hører til den tekniske tidsalders bestand:

Den gængse tale om menneskemateriale, om en kliniks menneskemateriale, taler for det. Den skovfoged, som... går sin runde ad de samme skovveje som sin bedstefar, er i dag bestilt af træforarbejdningsindustrien, hvad enten han ved det eller ej. Han er bestilt for bestilbarheden af cellulose... som tilstilles aviserne ... Disse tilstiller så den offentlige mening at sluge det trykte for at blive bestilbar for en bestilt meningsdannelse (Heidegger 1999, 47-8).

Dvs. Heidegger argumenterer for, at teknikken indlejrer (eller 'stiller', som Heidegger ville benævne det) mennesket i nye komplekse sammenhænge, der både forandrer dets forhold til sin omverden og omverdenens forhold til mennesket, samtidig med at teknikken ifølge Heidegger tildækker en mere oprindelig sandhed (ibid., 57). Denne tildækken af det Heidegger kalder den oprindelige sandhed, sker gennem det han kalder et 'stillads' (Gestell). Dette stillads udgør den samlede opstilling af teknik og andre praktikker, som påvirker det virkelige for mennesket (s. 53). Det afgørende 
ved Heideggers begreb stillads er, at det åbner for en analyse af alle former for menneskelige praktikker og deres forandring af menneskets relation til dets omverden og dermed også til sig selv.

Et eksempel på en sådan påvirkning af virkeligheden kan ses i forbindelse fremkomsten af smartphones, som de fleste danskere nu er i besiddelse af. På den ene side er en smartphone et middel til at opnå et mål, nemlig at kommunikere med andre mennesker samt gøre brug af diverse apps. I dette perspektiv er det altså os, der bruger telefonen til fx at ringe til andre. På den anden side har en smartphone i allerhøjeste grad indlejret moderne mennesker i en lang række nye sammenhænge, som vi næppe endnu på nogen måde kan overskue. I dette perspektiv er det ikke bare andre, der ringer til os evt midt i undervisningen, men selve det, at vi og vores adfærd er blevet en salgbar vare for reklamebranchen $\mathrm{mm}$. I dette perspektiv er vores levede liv og hverdagspraktikker via ny kommunikationsteknologi blevet en bestand for reklamebranchen, industri mm. Nu var Heidegger desværre ikke en filosof, der i særlig høj grad beskæftigede sig med menneskets sociale liv (Dreyfus 1996); men det er oplagt, at en smartphone indlejrer det moderne menneske i en lang række nye sammenhænge. Disse nye sammenhænge er både sociale, økonomiske, kulturelle, politiske og religiøse. Da internettet og sociale medier har medført fremkomsten af et regionalt opdelt men i princippet globalt socialt og kulturelt felt, hvori den enkelte kan positionere sig, kan man sige, at det moderne menneske via teknikken er blevet indlejret $\mathrm{i}$ et sæt nye relationer. En konsekvens af dette er, at det nu ikke længere er virksomheder, der forsøger at 'brande' sig i forhold til andre brands. I en online verden kan man iagttage, at også individer via sociale medier brander sig selv (Khamis Ang \& Welling 2017). Disse nye relationer er imidlertid ikke kun kulturelle og sociale, men er samtidig også økonomiske, da det moderne menneske er en forbruger, som tillader fx Facebook at registrere information om forbrugerens adfærd.

Uagtet at jeg ikke kan følge Heideggers romantiserende søgen efter det primitive og oprindelige menneskes væren som mere autentisk end moderne menneskers, så åbner Heideggers analyse for, at man både er opmærksom på, at teknik skylder sin fremkomst, at et eller flere mennesker har haft et formål hermed, og at man for det andet er opmærksom på, at teknik kan bevirke, at mennesker som konsekvens heraf indlejres i nye sammenhænge, og at teknikken dermed på afgørende vis påvirker det som Edmund Husserl og Alfred Schütz kaldte 'subjektets livsverden':

By the everyday life-world is to be understood that province of reality which the wideawake normal adult simply takes for granted in the attitude of common sense (Schutz \& Luckmann 1973, 3).

I forlængelse heraf kan man på baggrund af Heidegger argumentere for at fx en smartphone er blevet en del af det som tages for givet. Mere generelt kan man sige, at teknikken rækker ind - ikke blot i subjektets livsverden, men i selve subjektet, parallelt med Michel Foucaults argumentation for, at diskursen rækker ind i subjektet. Heideggers skrift om teknikken åbner for den indsigt, at mennesket i radikal forstand står i et dialektisk forhold til sin omverden, og at dette forhold påvirkes af eller måske 
ligefrem, at menneskets livsverden og dermed også mennesket som sådan konstitueres gennem blandt andet teknik. Dermed kan Heidegger bidrage til at vi kan opnå et dobbelt perspektiv på menneske og teknik. På den ene side er teknik et middel til at opnå et bestemt mål. På den anden side fanger bordet, idet teknikken forandrer menneskets relationer til sin omverden, hvad enten det er den fysiske omverden som Heidegger først og fremmest var optaget af, eller det er menneskets sociale verden eller en kombination af begge dele.

\section{Teknik og konstitueringen af religiøse distinktioner}

Som allerede anført er målet med artiklen at betragte ikke kun medier, men også religion i det bredest mulige perspektiv. Religion er jo som bekendt ikke kun betinget af teknik, men også af den øvrige kontekst. En vigtig del af denne øvrige kontekst er konstitutionen af andre centrale kollektiver som $\mathrm{fx}$ nationale distinktioner, der jo som bekendt har spillet en afgørende historisk rolle, ikke mindst siden de moderne stater satte Pavestolen uden for statssystemet ved indgåelsen af de westfalske fredsaftaler fra 1648.

For at opnå det bredest mulige generelle perspektiv vil jeg i det følgende for det første støtte mig på Jan Assmanns begreb om 'den mosaiske distinktion'. For det andet vil jeg gøre brug af Norbert Elias figurative sociologi og hans begreb om 'the extended-I-we-consciousness' samt nyere forskning i social ontologi og kollektive følelser. På denne baggrund er det muligt at skrive en religionernes og mere generelt distinktionernes historie som betinget af den samlede opstilling af menneskelige praksisformer inklusive medier og teknik.

I sin indflydelsesrige og omdiskuterede artikel "The Mosaic Distinction" og senere bøger hævdede den tyske ægyptolog og religionshistoriker Jan Assmann, at en ny og radikalt anderledes type religion var trådt ind i religionshistorien, da jødedommen $\mathrm{i}$ løbet af det første årtusind f.v.t. konstituerede sig som en monoteistisk religion (Assmann 1996, Assmann 1997, Assmann 2018):

The distinction with which this essay is concerned is the one between true and false in religion: a distinction that underlies the more specific ones between Jews and Gentiles, Christians and pagans, Muslims and unbelievers. Once this distinction is drawn, there is no end of reentries or subdistinctions. We start with Christians and pagans and end up with Catholics and Protestants, Calvinists and Lutherans, Socinians and Latitudinarians, and a thousand similar denominations and subdenominations ... The space severed or cloven by this distinction is the space of Western monotheism. It is the mental and cultural space constructed by this distinction that Europeans have inhabited for nearly two millennia. Let us call the distinction between true and false in religion the "Mosaic distinction" because tradition ascribes it to Moses (Assmann 1996).

Assmanns begreb, den mosaiske distinktion, er etableret på baggrund af matematikeren George Spencer-Browns 'matematiske skabelsesberetning' (Spencer-Brown 1969), der er en matematisk logisk beskrivelse af grundlaget for etablering af enhver form for distinktion og indikation (Spencer-Brown 1969, 1). Der er altså ingen nød- 
vendig grund til at knytte begrebet til monoteisme. For at løsne begrebet fra monoteisme vil jeg i stedet bruge begrebet 'den religiøse distinktion'. Det bør måske indskydes, at Spencer-Brown i øvrigt også er et vigtigt grundlag for den tyske sociolog Niklas Luhmann (Borch 2000). Imidlertid har Assmann en vigtig pointe, der også gælder for alle sproglige eller kulturelle distinktioner:

These cultural or intellectual distinctions construct a universe that is full not only of meaning, identity, and orientation but also of conflict, intolerance, and violence (Assmann 1996).

Der er dog efter min opfattelse ikke grund til nødvendigvis at antage, at religiøse distinktioner er historiske konstanter. Tværtimod ser de ud til at variere med den historiske kontekst i styrke eller intensitet. I perioder har de haft stor styrke, mens det i mindre grad har tilfældet i andre perioder. Den radikale og stærke udgave af den religiøse distinktion kan man iagttage under reformationstiden, hvor katolikker, lutheranere, kalvinister mm. bekæmpede og slog hinanden ihjel i et hidtil uset omfang. Resultatet af disse kampe var blandt andet at omkring en tredjedel af Europas befolkning i Det tysk-romerske Rige mistede livet.

En religiøs distinktion skaber imidlertid ikke kun mening, som var Assmanns hovedinteresse, men er også grundlaget for konstitueringen af sociale grupper, der netop konstitueres på baggrund af en distinktion mellem det Norbert Elias kalder en overlevelsesenhed (Elias 1978, 138-9) eller et socialt vi, der modstilles dem, der ikke er en del af dette sociale vi (Reeh 2013, 265). Et vigtigt element i Elias' tænkning er, at en overlevelsesenhed helt generelt er konstitueret i relation til en anden gruppe samt, at distinktionen betinger det Elias kalder en "extended-I-we-consciousness" (Elias 1978, 1974).

... the extended 'I-and-We' consciousness, which hitherto has always seemed indispensable in binding together not only small tribes but large social units like nation-states encompassing many millions of people. People's attachment to such large social units is often as intense as their attachment to a person they love. The individual who has formed such a bond will be as deeply affected when the social unit to which he is devoted is conquered or destroyed, debased or humiliated, as when a beloved person dies (Elias 1978, 137).

Denne "extended-I-we-consciousness" er desværre et lidt overset aspekt ved Elias' tænkning, men taler for en revitalisering af Durkheims begreb om den kollektive bevidsthed, som stort set ikke har været en del af det sociologiske standardvokabular siden blandt andre Marcel Mauss omformulerede begrebet kollektiv bevidsthed til kollektive repræsentationer (Mauss 1990). Nyere forskning peger på at sociale kollektiver kan og bør beskrives og analyseres som emergente fænomener som ikke kan reduceres til summen af individernes bevidsthed (Searle 1995; Schmid 2014; von Scheve 2014; Greve 2012):

What is the relation between singular and collective intentionality, for example, the facts described by "I intend" and "We intend"? Most efforts I have seen to answer this question try to reduce "We intentionality" to "I intentionality" plus something else, usually mutually held beliefs. The idea is that if we intend to do something together, 
then that consists in the fact that I intend to do it in the belief that you also intend to do it; and you intend to do it in the belief that I also intend to do it. ... It has seemed, in short, that we have to choose between reductionism, on the one hand, or a super mind floating over individual minds, on the other. I want to claim, on the contrary, that the argument contains a fallacy and that the dilemma is a false one. It is indeed the case that all my mental life is inside my brain, and all your mental life is inside your brain ... But it does not follow from that that all my mental life must be expressed in the form of a singular noun phrase referring to me. The form that my collective intentionality can take is simply "we intend," "we are doing so-and-so," and the like. In such cases, I intend only as part of our intending (Searle 1995, 24-26).

Hans Bernard Schmid går imidlertid videre og argumenterer for det han kalder plural self-awareness og plural selfhood:

it would be a mistake to conceive of plural self-awareness as distributive; rather, it joins the participant to a mental whole. Plural self-awareness of shared affective concerns is not anything single individuals have for themselves, distributively; it is something they have together, collectively, and that unites them to a self that is plural rather than singular. In the sense of plural selfhood, corporations can have emotions in terms of phenomenal states or feelings (Schmid 2014, 14).

Eksempler på et sådant pluralt selv er fx det vi, der taler i den amerikanske uafhængighedserklæring, der indledes med sætningen "We the People..." ${ }^{1}$ eller det kollektive 'vi', der taler i den apostolske trosbekendelse: “Vi forsager Djævlen...". ${ }^{2}$ Sådanne kollektive vi-konstruktioner er afhængige af teknik, da fx deres rækkevidde øges drastisk vha. kommunikative teknikker. Uden skrift kunne man formodentlig hverken have de religioner (Goody 1986) eller nationale vi-konstruktioner, som vi har i dag, og som kan omfatte millioner af mennesker. Menneskets livsverden (Schutz \& Luckmann 1973, 3), inklusive konstitutionen af kollektive vi-konstruktioner, er altså betinget af det man på baggrund af Heidegger kunne kalde den samlede tekniske opstilling. Her skal teknik forstås i bredest mulig forstand og som inkluderer ikke kun teknik i gængs forstand, men også sociale teknikker, som samlet har resulteret i konstruktionen af religioner og nationer.

\section{En skitse af de store distinktioners historie}

På baggrund af Heidegger, Elias, Searle og Schmid kan man således etablere en mere generel model, der fokuserer på teknikkens betydning for hvad man kunne kalde de historiske set afgørende distinktioner, nemlig stat og religion. Disse to distinktioner har nemlig på sin vis spillet en hovedrolle i de sidste fem tusinde års historie. Hovedpointen er som nævnt $\mathrm{i}$ indledningen hentet fra Heidegger, nemlig at teknik helt indlysende for det første kan ses, og som formodentlig i de fleste tilfælde kommer til verden, som et (teleologisk) middel til et mål og samtidig som en (kausal) årsag med en virkning i verden. For det andet og mindre indlysende virker teknikken tilbage på

\footnotetext{
https://www.archives.gov/founding-docs/constitution-transcript, set 5.4. 2020.

https://www.folkekirken.dk, set 5.4.2020.
} 
subjektet eller kollektivet ved at indlejre det i nye relationer, og ved at teknikken forandrer menneskets forhold til sin omverden. Den grundlæggende pointe, som vi kan tage med fra Heidegger, er altså, at teknik ikke kun er et middel til et mål, men at det også skaber en ny virkelighed, virker tilbage på subjektet ved at indlejre dette i nye relationer, og at teknikken dermed ændrer subjektet selv. Jeg skal understrege, at det følgende er en skitse og at jeg kun har medtaget, hvad jeg umiddelbart har fundet er de vigtigste hovedpunkter.

\section{Skriftløs religion og livsverden}

Dette tekniske regime kan karakteriseres ved fraværet af fikseret viden og dermed ved en fleksibel mundtlighed med hurtig fleksibilitet og tilpasningsevne, hvor personlig autoritet og legitimitet er afgørende (Goody 1986, 6ff; Rappaport 1999, 444). Endelig er dette tekniske regime karakteriseret ved, at viden har en begrænset udbredelse og rækkevidde, og at lagring af viden er begrænset til de enkelte individers hjernekapacitet. Som eksempel på dette kan vi tage den nordiske vikingetid. Kollektivets udstrækning før vikingetiden var begrænset, og de kollektive vi-konstruktioner har formodentlig været centreret omkring landsbyerne. Introduktionen af den teknik, der førte til konstruktion af vikingeskibe, var utvivlsomt afgørende både som militær, handels- og kommunikativ teknik. Når et vikingskib også må betragtes som kommunikativ teknik, er det, fordi det muliggjorde stærkt forbedrede transportmuligheder for mennesker. På grund af skibet blev vikingetidens mennesker i stand til at kommunikere over større afstande og dermed organisere sig i kollektiver (vikingekongedømmer), eller som Elias ville sige, i overlevelsesenheder, der var stærke nok til $\mathrm{fx}$ at indtage dele af de Britiske Øer.

\section{Skriftlig religion og livsverden}

Indledningsvis skal det nævnes, at skriftkultur ikke er en entydig størrelse, og at der historisk har eksisteret en række mellemformer, hvor skrift i nogle kulturer har været begrænset til fx religiøse eksperter, mens det $\mathrm{i}$ andre kulturer har været mere generelt udbredt som fx i de græske bystater. Skriftteknik har imidlertid overordnet set en række konsekvenser. Først og fremmest muliggør skrift autoritative hellige tekster eller kanon og dermed universalistiske religioner (Goody 1986, 10), eller det jeg her har kaldt religiøse distinktioner. Samtidig betyder skrift dels en mere fikseret viden og en formindsket tilpasningsevne (Rappaport 1999, 444 ff), dels en betydeligt større rækkevidde som eksemplificeret af Paulus breve. Ved hjælp af et skrevet brev var Paulus i stand til at kommunikere med kristne menigheder over lange afstande.

Introduktionen af skriftkultur ses naturligvis også i Danmark, idet skrift eller i hvert fald ideen om en hellig skift var en af de afgørende ting som de første engelske missionærer medbragte, da de ankom til Danmark. Skriftteknologien stod dog langt fra alene, men blev hurtigt ledsaget af en anden teknologi eller et andet medium, nemlig kirkelige bygninger, som efterhånden blev strøet ud over det danske landskab, hvorved hele befolkningen efterhånden blev indlejret i den kristne udgave af den mosaiske eller religiøse distinktion og romerkirkens økonomiske struktur med tiendebetaling etc. 


\section{Trykpressens religion og livsverden}

Trykpressen var som bekendt en medierevolution, der på afgørende vis ændrede Europa og verden. Martin Luther og måske især hans ligesindede var ikke sene til at udnytte det nye medie $\mathrm{fx}$ med de billige, men effektive flyveskrifter. Luthers kritik af det, han anså som Romerkirkens misbrug og forvrængninger af fundamentale kristne principper, blev hurtigt spredt ud over hele Europa. Mosaiske distinktioner havde med andre ord via trykpressen fået en stærkt forøget rækkevide. Mange var villige til at dø for deres tro, og syntes nok især at andre skulle dø, hvis de ikke troede på det samme som de selv gjorde. Resultatet rystede som bekendt Europa, der i de følgende år blev konfessionelt opdelt og gennemlevede de post-reformatoriske krige, der først kom til ende med de westfalske fredstraktater i 1648, hvor de europæiske stater accepterede de konfessionelle forskelle. Hvis man meget kort skal sammenfatte denne lange og komplicerede historiske udvikling kan man sige, at fremkomsten af trykpressen bidrog til at destablisere den førreformatoriske verdensorden og muliggjorde blandt meget andet en hurtig udbredelse af nye revolutionære religiøse ideer. I den efterfølgende periode fik man lidt efter lidt stabiliseret situationen vha. sociale teknikker som fx censur og statslige universiteter, der kunne underbygge de nye staters verdensorden. Med de westfalske fredstraktater fra 1648 anerkendte de europæiske stater gensidigt den nye orden og man kan derfor sige, at omkalfatringen af den førreformatoriske orden var gennemført og at der nu var etableret en ny.

Springer vi frem i tid til perioden efter den franske revolution, kan man gradvist iagttage fremkomsten af en ny distinktion, nemlig den nationale distinktion, der efterhånden skulle vise sig at overtrumfe de religiøse distinktioner. Denne nye or revolutionerende nationale distinktion viste sig eksempelvis i den franske nationalsang marseillaisen fra 1792 og i det forhold at de nye franske nationale militære enheder hurtigt viste sig at være de gamle regimers lejesoldater overlegne (Kaspersen 2004)(82ff). I en dansk sammenhæng udbredes den patriotiske distinktion (som Assmann måske ville kalde det) eller et patriotisk vi (Elias) fra slutningen af 1700-tallet og mere systematisk fra skoleloven af 1814. I denne sammenhæng, hvor fokus er på medier og teknik, bør det måske lige indføjes, at skole også kan anskues som medie og teknik og at disse statslige teknikker udbredes betydeligt i perioden fra reformationen og frem. Trykpressen muliggjorde altså en voldsom udbredelse af bøger og læsning. Efter reformationen i Danmark ophøjede staten Luthers Lille Katekismus til samfundets grundlæggende rettesnor og stillede krav om at husfaderen skulle oplære sit hus (kone, børn og tjenestefolk) i den. ${ }^{3}$ Dette krav skærpedes ved indførelsen af det tvungne konfirmation i 1736, hvor pensum blev væsentligt udvidet og der nu blev stillet krav om at alle skulle konfirmeres og skulle kunne, ikke bare katekismen, der var på omkring ti normalsider, men også i Pontoppidans Forklaring, der var en bog på omkring 200 sider. Med skoleloven af 1739 fulgte staten op på dette og indførte tvungen skolegang for alle.

De tekniske forudsætninger for skolegang var nu tilstede, idet teknikkerne til fremstilling af jern og vinduesglas var blevet tilstrækkeligt billige til, at man kunne 
sørge for to forudsætninger for skole, nemlig en nogenlunde varm stue med tilstrækkeligt lys til at børnene kunne læse. Etablering af skolemediet eller skoleteknikken hvilede altså på andre teknikker, som fremstilling af jern og glas.

Ovenfor argumenterede jeg for, at Heidegger kunne bruges til en skærpet opmærksomhed på det forhold, at teknik for det første er et middel til et mål, men at det også virker tilbage på subjektet da det potentielt omformer subjektets relation til dets omverden. I forlængelse heraf kan man overveje, om dette ikke kun gælder for individet, men potentielt også for en stat. Statens mål med indførelsen af den tvungne skoleteknik var i udgangspunktet at disciplinere befolkningen (Reeh 2009). Dette betød dels en betydelig forbedring af læsefærdighederne i hele befolkningen, dels at befolkningen fik et ensartet sprog, nemlig dansk. Enevældens skolegang fik meget hurtigt store konsekvenser. Først og fremmest var der er del, der tog religionsundervisningen betydeligt mere alvorligt end tilsigtet, idet man ikke var tilfredse med statskirkens præster. Det medførte, at man begyndte en selvstændig religiøs organisering i såkaldte konventikler, som staten sidenhen fik store problemer med. For det andet betød den sproglige harmonisering og udbredelsen af en patriotisk/national diskurs, at forudsætningerne for etablering af en national Vi-konstruktion tilvejebragtes. Ifølge den preussiske general Carl von Clausewitz og den moderne militære tænknings grundlægger var den nationale organisering på grundlag af den nationale distinktion langt stærkere end andre daværende statslige organisationsformer. Ifølge Clausewitz var der nemlig med den franske revolution sket det, at det franske folk var blevet en aktiv deltager i krig. Krig førtes ikke længere af regering og hær, men af hele den franske nation. De ressourcer og den kampvilje, som nu kunne kastes ind i krigen, overgik alt, hvad man hidtil havde kendt, og konsekvensen var, at Frankrigs fjender befandt sig i den yderste fare (Clausewitz 1993, 715-6). De nationale distinktioner indebar på den ene side en voldsom militær styrkelse af de europæiske stater, idet mange borgere fra og med den franske revolution nu var villige til at dø for fædrelandet, hvilket resulterede $i$, at de frivillige nationale enheder var de traditionelle lejesoldater langt overlegne (Kaspersen 2004). På den anden side betød de nationale distinktioner, at de europæiske konger i løbet af 1800-tallet i varierende grader måtte afgive magten til folket, hvilket næppe var en del af planen, da man indførte patriotisk fædrelandshistorie i 1814.

I denne epoke kan vi altså iagttage først etablering af trykpressen med alt hvad deraf fulgte, og dernæst at staten søgte at kontrollere læsefærdigheden via censur og skole, og endelig etableringen af en national distinktion, som hurtigt viste sig at være endog meget stærk.

\section{Massemediernes religion og livsverden}

De næste afgørende medieteknikker, der blev introduceret var naturligvis radio, tv og film. Overordnet set betød massemedierne en stærkt forøget rækkevidde og et stærkt forøget medieforbrug. I denne sammenhæng spillede massemedierne en afgørende rolle dels i forbindelse med udbredelsen af amerikansk populærkultur og for en tværnational ungdomskultur fra 1960erne og frem, der både fik stor betydning for ungdomsoprøret, hippiebevægelsen, etc. Måske kan man ligefrem sige, at det kunne 
begynde at minde om en vestlig offentlighed, der godt nok stadig var nationalt opdelt, men at man i høj grad diskuterede samme temaer, problemer mm.

I denne sammenhæng er det dog vigtigt at være opmærksom på, at medieteknikken og dens påvirkning af religion for det første ikke har været ensartet $\mathrm{i}$ alle lande. I USA var der fx fra fjernsynets fremkomst ikke tale om et statsligt monopol, som det fx var tilfældet i Danmark. Denne forskel betød, at medieteknikken i Danmark ikke umiddelbart, som det var tilfældet i USA, betød, at der blev etableret tv-kanaler med et religiøst formål. Analogt til de statslige universiteter, som man havde etableret som en form for sikring og kontrol med viden efter trykpressen, havde man umiddelbart efter anden verdenskrig et statsligt monopol med tv og radio. Derudover betød den såkaldte partipresse, at journalistik og nyhedsdækning var underlagt en politisk organiseret redaktion. Det statslige tv-monopol og partipressen brød først sammen med den nye opstilling af tekniske og sociale teknikker som fulgte i kølvandet de store liberaliseringer i 1980erne, indførelsen af New Public Management, og ikke mindst internettets kommercielle etablering i årene efter 1990.

\section{Internettets religion og livsverden}

I det følgende skal fokus ligge på, at individet ikke kun gør brug af teknik, men også selv kan blive en bestand via teknikkens indlejring af mennesket i nye relationer. Inden vi når til dette Heidegger-inspirerede perspektiv er der imidlertid en række åbenbare konsekvenser af internettet:

1. Kommunikation nu har global rækkevidde. Konsekvensen af dette er øget relativering og, hvad man kunne kalde hyperrelativering.

2. Kommunikation opleves som gratis for individet. Det er imidlertid mere rammende at sige at man betaler ved at lade sin adfærd registrere særligt af en række få, men meget magtfulde, såkaldte Big Tech-firmaer som Apple, Google, Facebook og Twitter.

3. Kommunikation kan i meget højere grad frit vælges af individet, hvilket får den konsekvens, at individerne selv foretager en omfattende selvsortering, der medfører fremkomsten af distinkte og delvist lukkede kommunikationsfora.

4. Kommunikationens indhold er ikke underlagt redaktion, bortset fra den der udøves af Big Tech-firmaerne, der kan lukke fx en Facebook profil, hvis man overtræder Facebooks regler.

5. Kommunikationen opleves som potentielt anonym $\mathrm{fx}$ via en brugerprofil, som ofte kan oprettes med et andet navn end ens eget. Denne anonymisering er dog kun tilsyneladende, da kommunikationen bruges kommercielt i forbindelse med markedsføring, inklusive markedsføring af politiske synspunkter i forbindelse med valgkampe.

Samlet set har dette medført fremkomsten af såkaldte 'ekkokamre' (Colleoni, Rozza \& Arvidsson 2014) hvor individer isolerer sig og kun kommunikerer med andre individer som ligner dem selv, og at både individer og grupper via Big Tech-firmaernes 
registrering af internetadfærd er blevet til det Heidegger vil kalde en bestand for marketing $\mathrm{mm}$.

Umiddelbart kan man hævde, at dette ikke har meget med religion at gøre. Vender man imidlertid blikket mod USA, bliver det hurtigt klart, at den tekniske og især mediernes udvikling har spillet en hovedrolle i organiseringen af det Robert Wuthnow kalder 'det religiøse højre' i USA i sin fremragende bog Red State Religion (Wuthnow 2012). I denne bog skildrer Wuthnow fremkomsten og organiseringen af det religiøse højre i USA, som ikke fandtes før 1960erne. Ifølge Wuthnow opstod det religiøse højre i USA som en reaktion på 1) ungdomsoprøret, 2) at den amerikanske højesteret i 1948 udstrakte adskillelsen af religion og politik til ikke kun at gælde det føderale niveau, men også på delstatsniveauet og 3) indførelsen af fri abort med højesteretskendelsen Roe v. Wade i 1972. Som stifteren af Moral Majority, Jerry Fallwell udtrykte det, var der sket det, at "God has been kicked out of the public square" (Nathaniel 2007, 522). Konsekvensen af følelsen af at blive løbet over ende af sekularisering blev i løbet af 1970erne til en religiøs organisering, hvor massemedierne spillede en central rolle (Wuthnow 2012, 313 ff). I dag er denne udvikling ført videre med etableringen af en række politiske paralleluniverser. Et udgøres af "the mainstream media" (MSNBC, CNN, Washington Post, New York Times etc.), og et andet af det amerikanske evangelikale kristne højre, der er centreret omkring Fox News og en underskov af radio, tv og internetmedier som fx Breitbart.com. Mht. udviklingen af det amerikanske kristne højre er der ingen tvivl om, at dets fremkomst oprindeligt skyldtes et ønske om at bruge den nye teknik som redskab i den kristne sags tjeneste. Ny forskning viser imidlertid, at amerikanernes religion i dag påvirkes af en variabel som ikke synes at spille en rolle i forskningen om religion og medier (Campbell \& Vitullo 2016). Den 'nye' variabel er den politiske distinktion mellem republikanere og demokrater, idet ny forskning peger på, at amerikanerne i dag tilpasser resten af deres identitet til deres politiske ståsted, inklusive fx tøjstil og religion (Margolis 2016; Egan 2018). Også her er det med andre ord gået som i de eksemplerne ovenfor, idet denne gruppe både som individer og gruppe nu er blevet til en bestand for både politiske valgkampagner og for reklameindustrien, hvilket blev dygtigt udnyttet af både Det Russiske Internet Agentur og firmaet Cambridge Analytica, der formodentlig var en medvirkende faktor bag Donald Trumps valgsejr i 2016 (Dewi \& Randhi 2018). Dette fænomen er selvsagt ikke begrænset til USA, idet politisk cyber-campaigning også har vundet indpas i Danmark (Hansen \& Kosiara-Pedersen 2014). Hvordan dette skal begribes teoretisk, er imidlertid et godt spørgsmål, som fremtidig forskning er nødt til at tage op. På den ene side er der som nævnt tale om at internettet virker anonymiserende, hvilket i en traditionel optik ville medføre en højere grad af privatisering af religion. På den anden side er kommunikationen ikke anonym for kommerciel markedsføring, hvilket betyder at individet bliver indlejret både i kommerciel og politisk markedsføring. Individets religion er potentielt dermed blevet et politisk og kommercielt redskab og må i fremtiden tænkes og begribes som sådan. 


\section{Afrunding}

I det ovenstående har jeg forsøgt at opstille en skitse af hvordan religion og teknik, herunder medier kan begribes ved hjælp af Heideggers begreb Gestell, der skærper opmærksomheden på det forhold at teknik dels er et redskab for mennesket, dels at det forandrer menneskets forhold til sin omverden på radikal vis ved at indlejre mennesket i nye relationer. Mennesket bliver som det er fremgået dermed det Heidegger kalder en bestand i disse nye relationer. I det lange historiske perspektiv har teknikken gjort mennesket til en bestand. Dette gælder også for statslige og religiøse distinktioner. Disse to historisk set afgørende distinktioner har siden den romerske stats kamp mod kristendommen eksisteret i et spændingsfyldt indbyrdes forhold, der på afgørende vis har været influeret af teknik og særligt medieteknik i bred forstand som fx kirker, skoler, trykpresse, massemedier og internet. Efter massemediernes og især internettets fremkomst er det individuelle menneske blevet indlejret i nye sammenhænge, således at mennesket $\mathrm{i}$ endnu højere grad er blevet det Heidegger kalder en bestand for kommerciel og politisk markedsføring både fra indenlandske og udenlandske aktører gennem såkaldt cyber-campagning. Og det ser endvidere ud til at fx amerikanere pt. tilpasser deres religion og religiøse tilhørsforhold til distinktionen mellem republikanere og demokrater. Hvis dette viser sig at holde på længere sigt, må religionsvidenskaben medtænkte, at religion fra og med internettets etablering udspiller sig i et nyt miljø.

\section{LITTERATUR:}

Assmann, Jan. 1996. "The Mosaic Distinction: Israel, Egypt, and the Invention of Paganism." Representations (56):48-67. doi: 10.2307/2928707.

Assmann, Jan. 1997. Moses the Egyptian : the memory of Egypt in western monotheism. Cambridge, Mass.: Harvard University Press.

Assmann, Jan 2018. The invention of religion: faith and Covenant in the Book of Exodus. Princeton: Princeton University Press.

Borch, Christian. 2000. "Former, der kommer i form - om Luhmann og SpencerBrown." Distinktion: Journal of Social Theory 1 (1):105-122. doi: 10.1080/1600910X.2000.9672774.

Campbell, Heidi A., and Alessandra Vitullo. 2016. "Assessing changes in the study of religious communities in digital religion studies." Church, Communication and Culture 1 (1):73-89. doi: 10.1080/23753234.2016.1181301.

Clausewitz, Carl von (1989). On war. ed. and transl. by Michael Howard and Peter Paret introductory essays by Peter Paret, Michael Howard, and Bernard Brodie with a commentary by Bernard Brodie index by Rosalie West. Princeton, N.J., Princeton University Press.

Colleoni, Elanor, Alessandro Rozza \& Adam Arvidsson (2014). "Echo chamber or public sphere? Predicting political orientation and measuring political homophily in Twitter using big data." \ournal of communication 64(2): 317-332. 
Danmarkhistorien.dk. 1537/39. Kirkeordinantsen. edited by Denmark. København. de Vries, Willem A. 1991. "The Dialectic of Teleology." Philosophical Topics (Fall):5170.

Dewi, Masruroh, and Satria Randhi. 2018. "The Effect of Cambridge Analytica Case in Cyberspace Politics." 5th International Conference on Social and Political Sciences (IcoSaPS 2018), 2018/08.

Dreyfus, Hubert L. 1996. "Being and power: Heidegger and Foucault." International Journal of Philosophical Studies 4 (1):1-16. doi: 10.1080/09672559608570822.

Egan, Patrick J. 2018. "Identity as Dependent Variable: How Americans Shift Their Identities to Better Align With Their Politics." Wilf, Department of Political Science, New York University.

Elias, Norbert. 1974. "The Sociology of community : a selection of readings." In New sociology library, edited by Colin Bell and Howard Newby, lii, 355 p. London: Cass.

Elias, Norbert. 1978. What is sociology?, European perspectives. New York: Columbia University Press.

Folkekirken. 2019. "Den apostolske Trosbekendelse." In. https://www.folkekirken.dk/_Resources/Persistent/5/c/b/d/5cbd8c0067f9675a 685375174b2cc54fed2114a6/Den-apostolske-Trosbekendelse.pdf.

Goody, Jack. 1986. The logic of writing and the organization of society, Studies in literacy, the family, culture and the state. Cambridge: Cambridge University Press.

Greve, Jens. 2012. "Emergence in Sociology: A Critique of Nonreductive Individualism." Philosophy of the Social Sciences 42 (2):188-223. doi: 10.1177/0048393110381770.

Hansen, Kasper M., and Karina Kosiara-Pedersen. 2014. "Cyber-Campaigning in Denmark: Application and Effects of Candidate Campaigning." Journal of Information Technology \& Politics 11 (2):206-219. doi: 10.1080/19331681.2014.895476.

Heidegger, Martin. 1999. Spørgsmålet om teknikken - og andre skrifter. Edited by Dan Zahavi, Moderne tænkere. København: Gyldendal.

Hjarvard, Stig. 2012. "Three Forms of Mediatized Religion. Changing the Public Face of Religion." In Mediatization and religion : Nordic perspectives, edited by Stig Hjarvard and Mia Lövheim. Göteborg: Nordicom, University of Gothenburg.

Højrup, Thomas. 2002. Dannelsens dialektik etnologiske udfordringer til det glemte folk redaktion ...: Marie Sandberg, Etnologiske studier. Kbh.: Museum Tusculanum.

Kaspersen, Lars Bo. 2004. "How Denmark Became Democratic. The Impact of Warfare and Military Reforms." Acta Sociologica 47 (1).

Khamis, Susie, Lawrence Ang, and Raymond Welling. 2017. "Self-branding, 'microcelebrity' and the rise of Social Media Influencers." Celebrity Studies 8 (2):191208. doi: 10.1080/19392397.2016.1218292.

Mauss, Marcel. 1990. The gift : the form and reason for exchange in archaic societies. London: Routledge. 
Margolis, Michele F. 2016. "Cognitive Dissonance, Elections, and Religion: How Partisanship and the Political Landscape Shape Religious Behaviors." Public Opinion Quarterly 80 (3):717-740. doi: 10.1093/poq/nfw023.

Nathaniel, J. Klemp. 2007. "Beyond God-Talk: Understanding the Christian Right from the Ground Up." Polity 39 (4):522-544.

Rappaport, Roy A. 1999. Ritual and religion in the making of humanity, Cambridge studies in social and cultural anthropology. Cambridge: Cambridge University Press.

Reeh, Niels. 2009. "Ideas and State Subjectivity in History, the introduction of the equestrian schools in 1720 and the confirmation in 1736." Ideas in History V (3):83-110.

Reeh, Niels. 2013. "A Relational Approach to the Study of Religious Survival Units." Method \& Theory in the Study of Religion Volume 25 (Issue 3):264 - 282 doi: 10.1163/15700682-12341261.

Schmid, Hans Bernhard. 2014. "The feeling of being a group: corporate emotions and collective consciousness." In Collective Emotions, edited by Christian von Scheve and Mikko Salmela. Oxford: Oxford University Press.

Schutz, Alfred, and Thomas Luckmann. 1973. The structures of the life-world [by] Alfred Schutz and Thomas Luckmann. Translated by Richard M. Zaner and H. Tristram Engelhardt, Jr: Evanston [Ill.] Northwestern University Press.

Searle, John R. 1995. The construction of social reality. New York: Free Press.

Spencer-Brown, G. 1969. Laws of form. London: Allen \& Unwin.

USA. 2019. US Constitution.

von Scheve, Christian. 2014. Collective emotions: perspectives from psychology, philosophy, and sociology. 1. ed, Series in affective science. Oxford u.a.: Oxford Univ. Press.

Wuthnow, Robert. 2012. Red state religion: faith and politics in America's heartland. Princeton: Princeton University Press.

Niels Reeh, lektor, ph.d. Religionsstudier, Syddansk Universitet 